\title{
Effect of Docosahexaenoic Acid on Lipoprotein Synthesis and Secretion by Cultured Eel Hepatocytes
}

\author{
Jibril Ndiaye* $^{*}$ and Seiichi Hayashi** \\ *The United Graduate School of Agricultural Science, Kagoshima University, Kagoshima 890, Japan and \\ **Laboratory of Food Chemistry, Faculty of Fisheries, Kagoshima University, Kagoshima 890, Japan
}

Key words: eel/cultured hepatocytes/docosahexaenoic acid/lipoprotein

\begin{abstract}
$A B S T R A C T$. We investigated effect of docosahexaenoic acid on lipoprotein synthesis and secretion by cultured eel hepatocytes. When eel hepatocytes were incubated with $1 \mathrm{mM}$ docosahexaenoic acid (DHA) at $28^{\circ} \mathrm{C}$ for $24 \mathrm{~h}$, triacylglycerol (TG), free cholesterol (FC), and cholesteryl ester (CE) syntheses from ${ }^{14} \mathrm{C}$-acetate increased 9.7-, 1.6-, and 8.5-fold, respectively, and the specific activity of TG was twofold that of control. These results indicate the stimulative effect of DHA on lipid synthesis. However, the radioactivity of the lipoprotein secreted by DHA-treated cells incubated with ${ }^{14} \mathrm{C}$-acetate and ${ }^{3} \mathrm{H}$-leucine reduced to 55 and $60 \%$, respectively, compared to that by control cells, but DHA did not affect the incorporation of ${ }^{3} \mathrm{H}$-leucine into other secreted protein. Furthermore, the amount of the secreted lipoprotein per $24 \mathrm{~h}$ by DHA-treated cells also reduced to $17 \%$. These results show that DHA inhibits the secretion of lipoprotein. Intracellular lipids such as TG, PL, and TC increased by 4.8, 1.6, and 1.8 times, respectively, in DHA-treated cells. The remarkable increase in TG in DHA-treated cells seems to be due to the stimulative effect of DHA on TG synthesis and an inhibitory effect of DHA on lipoprotein secretion, since about $70 \%$ of the secreted lipoprotein consists of TG. The chemical composition and apoprotein profile of the lipoprotein secreted by DHA-treated and control cells were almost the same. These results suggest that DHA inhibits the assembly or secretion of the lipoprotein in eel hepatocytes.
\end{abstract}

It is known that fish oil contains high unsaturated fatty acids (HUFA) such as docosahexaenoic acid (DHA) and eicosapentaenoic acid (EPA) $(2,7)$, and that DHA and EPA are essential fatty acids for growth and survival of fish $(5,21,22)$. These fatty acids are contained as components in triacylglycerol (TG), phospholipid (PL), and cholesterol ester (CE) of fish serum lipoproteins such as very low density lipoprotein (VLDL) and high density lipoprotein (HDL). We have reported previously that addition of eel serum VLDL or HDL stimulates the synthesis and secretion of the lipoprotein by cultured eel hepatocytes $(14,25)$.

Many reports of effect of feeding fish oils on serum lipoproteins of human $(6,10,13)$, rat (23) and rabbit (1) indicate the decrease of VLDL secretion, resulting in the reduction of serum TG. However, it was reported that carp dietary HUFA containing DHA and EPA did not reduce serum TG significantly (18). Fish oil is digested by pancreatic lipase and absorbed into epithelial cells of intestine, where cells reconstitute chylomicron

\footnotetext{
** To whom correspondence should be addressed.

Tel: 099-286-4200, Fax: 099-286-4015

Abbreviations: DHA, docosahexaenoic acid; EPA, eicosapentaenoic acid; TG, triacylglycerol; PL, phospholipid; TC, total cholesterol; CE, choresteryl ester; FC, free cholesterol; FA, fatty acid; VLDL, very low density lipoprotein; HDL, high density lipoprotein.
}

from absorbed fatty acids and secrete it. The liver incorporates chylomicron remnant after hydrolysis of chylomicron by lipoprotein lipase through circulation, decomposes it to TG, PL, CE, FC, fatty acids containing DHA and EPA, and amino acids, and these products influence the synthesis and secretion of lipoprotein in liver. Eel serum HDL containing DHA and EPA stimulated the synthesis and secretion of the lipoprotein by cultured eel hepatocytes (14). We then sought to clarify whether the effect of DHA on lipoprotein metabolism in cultured eel hepatocytes was the same as to those reported using cultured hepatocytes of mammals.

Addition of $1 \mathrm{mM}$ DHA to eel hepatocytes decreased the secretion of lipoprotein as well as the amount of the radioactivity of the lipoprotein incorporating ${ }^{14} \mathrm{C}$-acetate or ${ }^{3} \mathrm{H}$-leucine, and increased the intracellular lipid content and lipid synthesis from ${ }^{14} \mathrm{C}$-acetate.

\section{MATERIALS AND METHODS}

Materials. Leivobits L-15 and fetal bovine serum (FBS) were obtained from Life Technology. L-[4,5-3 $\mathrm{H}]-$ Leucine $(2.4 \mathrm{TBq} / \mathrm{mmol})$ and $\left[1(2)-{ }^{14} \mathrm{C}\right]$ acetic acid sodium salt $(2.11$ $\mathrm{GBq} / \mathrm{mmol}$ ) were purchased from Amersham Japan. Sephadex-G-25 was obtained from Pharmacia Japan. Collagenase, insulin from bovine pancreas, and cis-4,7,10,13,16,19-docosa- 
hexaenoic acid ethyl ester were from Wako Pure Chemical Ind. Enzymatic kits for lipid analysis were from Kyowa Medex. Plastic dishes ( 9 and $6 \mathrm{~cm}$ ) were obtained from Sumitomo Bakelite Co. Other chemicals were purchased from Wako Pure Chemical Ind. or Nakarai Tesque.

Eels weighing 200 to $250 \mathrm{~g}$ were purchased from Sueyoshi Co. in Kagoshima and were starved for several days before experiments.

Primary culture of hepatocytes. Isolated hepatocytes were prepared by collagenase digestion of a perfused liver and cultured as described previously $(8,9)$.

Docosahexaenoic acid solution. Docosahexaenoic acid (DHA) was dissolved at a concentration of $100 \mathrm{mM}$ with dimethyl sulfoxide and used at a final concentration of $1 \mathrm{mM}$ in cultured medium. To control medium only an equal volume of dimethyl sulfoxide was added.

Incorporation of ${ }^{14} \mathrm{C}$-acetate into intracellular lipids and the secreted lipoprotein. Hepatocytes in a $10 \mathrm{~cm}$ dish cultured for 5 days were washed with FBS- and insulin-free L-15 medium and incubated in $7 \mathrm{ml}$ of the same medium containing $10.57 \mathrm{kBq} / \mathrm{ml}$ of ${ }^{14} \mathrm{C}$-acetate with or without $1 \mathrm{mM} \mathrm{DHA}$ at $28^{\circ} \mathrm{C}$ for $24 \mathrm{~h}$. After incubation, the medium was recovered and hepatocytes were washed with $3 \mathrm{ml}$ of PBS. The medium and the PBS used to wash the cells were combined and centrifuged for $5 \mathrm{~min}$ to remove cells and cell debris at 3,000 rpm. The supernatant was used for lipoprotein fractionation by density gradient ultracentrifugation. Radioactivity of each fraction was counted by a liquid scintillation counter (Aloka LS-3500).

After washing with PBS, $0.75 \mathrm{ml}$ of methanol was added to the hepatocytes on a dish. The cells were scraped with a silicon rubber policeman and recovered into a glass tube with a stopper. The dish was washed twice with $0.65 \mathrm{ml}$ of methanol and the methanol used to wash the dish was combined with the recovered cells in the glass tube. To the glass tube containing the recovered cells, $0.63 \mathrm{ml}$ of chloroform and $0.5 \mathrm{ml}$ of water were added and the mixture was vigorously shaken. The mixture was left for $2 \mathrm{~h}$ at room temperature and then centrifuged at 3,000 rpm for $10 \mathrm{~min}$. The supernatant was transferred to another glass tube and the precipitate was reextracted with $2.38 \mathrm{ml}$ of chloroform-methanol-water (1:2:0.8). After centrifugation, supernatant was combined and the precipitate dried under $\mathrm{N}_{2}$ stream was dissolved with $2 \mathrm{ml}$ of 0.1 $\mathrm{N} \mathrm{NaOH}$ for radioactivity measurement and protein assay as intracellular protein. Chloroform $(1.25 \mathrm{ml})$ and water $(1.25$ $\mathrm{ml})$ were added to the combined supernatant and centrifuged. The chloroform layer was recovered and evaporated to dryness under $\mathrm{N}_{2}$ stream. Extracted lipids were dissolved in $200 \mu \mathrm{l}$ of 5\% Triton X-100 and lipids in 5\% Triton X-100 were assayed by enzymatic methods.

Fractionation of lipoprotein by a Superose $12 \mathrm{HR}$ 10/30 column. Gel-filtration by a Superose $12 \mathrm{HR}$ column was used to separate lipoprotein from proteins secreted by cultured hepatocytes. We reported previously that a secreted lipoprotein was a VLDL- (or chylomicron-) like one (24). As shown in
Fig. 1A, eel serum VLDL, HDL, and other proteins were separated by the Superose $12 \mathrm{HR}$ column. Eel serum VLDL and HDL were prepared by density gradient ultracentrifugation as described elsewhere (24).

After hepatocytes were incubated with FBS- and insulinfree $\mathrm{L}-15$ medium containing $10.57 \mathrm{kBq} / \mathrm{ml}$ of ${ }^{14} \mathrm{C}$-acetate or $26.43 \mathrm{kBq} / \mathrm{ml}$ of ${ }^{3} \mathrm{H}$-leucine with or without DHA at $28^{\circ} \mathrm{C}$ for $24 \mathrm{~h}$, the medium was taken into a glass tube and centrifuged for $5 \mathrm{~min}$ to remove cells and cell debris at 3,000 rpm. The supernatant was filtrated with a membrane with $3.0 \mu \mathrm{m}$ pore size (Millipore) and $100 \mu \mathrm{l}$ of the filtrate was applied to a Superose 12 HR column equilibrated with PBS.

Extraction of lipid from the secreted lipoprotein. To extract the lipid of the secreted lipoprotein, $480 \mu \mathrm{l}$ of chloroform-methanol $(1: 2)$ and $100 \mu$ l of methanol were added to $200 \mu l$ of the secreted lipoprotein in a glass tube with a stopper. The mixture was vigorously shaken and left for $2 \mathrm{~h}$ at room temperature. The glass tube was centrifuged at 3,000 rpm for $5 \mathrm{~min}$. The supernatant was put into another glass tube, and the precipitate was reextracted with $480 \mu$ l of chloroform-methanol-water $(1: 2: 0.8)$ and recentrifuged. The supernatant was combined and $300 \mu$ of chloroform and water were added to the combined supernatant. The combined supernatant was mixed, centrifuged and the chloroform layer was recovered. The chloroform layer was evaporated to dryness under $\mathrm{N}_{2}$ stream. Lipid classes were separated by thinlayer chromatography (TLC).

Fractionation of lipoprotein by ultracentrifugation. Secreted and serum lipoproteins were fractionated by density gradient ultracentrifugation (4). Medium containing the lipoprotein secreted by cultured hepatocytes was applied to a Sephadex G-25 column $(1.6 \times 15 \mathrm{~cm})$ equilibrated with phosphate buffered saline (PBS) to isolate the protein fraction. $\mathrm{KBr}$ was added to the protein fraction eluted from a Sephadex G-25 column at $0.4 \mathrm{~g}$ per $\mathrm{ml}$ and an equal volume of $0.75 \%$ $\mathrm{NaCl}$ was laid over the $\mathrm{KBr}$ solution in a centrifuge tube. The secreted lipoprotein was fractionated by density gradient ultracentrifugation at $40,000 \mathrm{rpm}$ for $16 \mathrm{~h}$ at $15^{\circ} \mathrm{C}$ in a $70 \mathrm{Ti}$ rotor using an Optima L-80 centrifuge (Beckman).

Incorporation of ${ }^{3} \mathrm{H}$-leucine into intra- and extracellular proteins. Hepatocytes cultured for 5 days with L-15 medium containing $5 \%$ FBS and $0.16 \mu \mathrm{M}$ insulin were washed with FBS- and insulin-free L-15. The cells were incubated with the same medium containing $26.43 \mathrm{kBq} / \mathrm{ml}$ of ${ }^{3} \mathrm{H}$-leucine with or without DHA at $28^{\circ} \mathrm{C}$ for $24 \mathrm{~h}$. After incubation, the medium was applied to a Superose $12 \mathrm{HR}$ column or density gradient ultracentrifugation to separate the secreted lipoprotein and other secreted proteins as described above.

Hepatocytes on a dish were washed with $3 \mathrm{ml}$ of PBS and 3 $\mathrm{ml}$ of $0.1 \mathrm{~N} \mathrm{NaOH}$ was added to the cells. The lysed cells were placed in a glass tube. The dish was washed twice with $1 \mathrm{ml}$ of $0.1 \mathrm{~N} \mathrm{NaOH}$ and the washing solution was combined in the same test tube. Protein of lysed cells in $5 \mathrm{ml}$ of $0.1 \mathrm{NaOH}$ was precipitated with $1.3 \mathrm{ml}$ of $50 \%$ trichloroacetic acid (TCA) and centrifuged at 3,000 rpm for $5 \mathrm{~min}$. The precipitate was 
washed with $2 \mathrm{ml}$ of $5 \%$ TCA three times and dissolved with $2 \mathrm{ml}$ of $0.1 \mathrm{~N} \mathrm{NaOH}$ for radioactivity measurement and protein assay.

$T L C$ and analysis of protein and lipid. Extracted lipid $(10 \mu \mathrm{l})$ was applied to a TLC aluminum sheet precoated silica gel $60 \mathrm{~F}_{254}$ (E. Merck), and n-hexane-diethylether-acetate (80:20:1) was used as developing solvent. After developing, the sheet was sprayed with $50 \%$ sulfate, and each lipid was detected by heating the sheet at $150^{\circ} \mathrm{C}$. Tripalmitateglycerol, cholesterol, cholesteryl palmitate, and lecithin were used as standards and carriers.

Protein was assayed by the method of Bradford (3) in the range of $0.1-1.5 \mathrm{mg} / \mathrm{ml}$ and by the method of Smith et al. (19) in the range of $1-20 \mu \mathrm{g} / \mathrm{ml}$. Triacylglycerol (TG), phospholipid (PL), total (TC) and free cholesterol (FC) contents of ex-

\section{A}

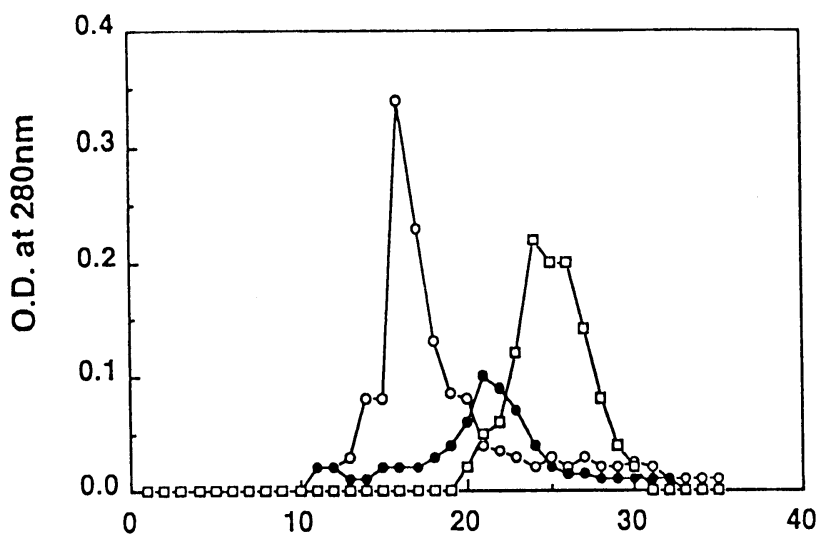

B

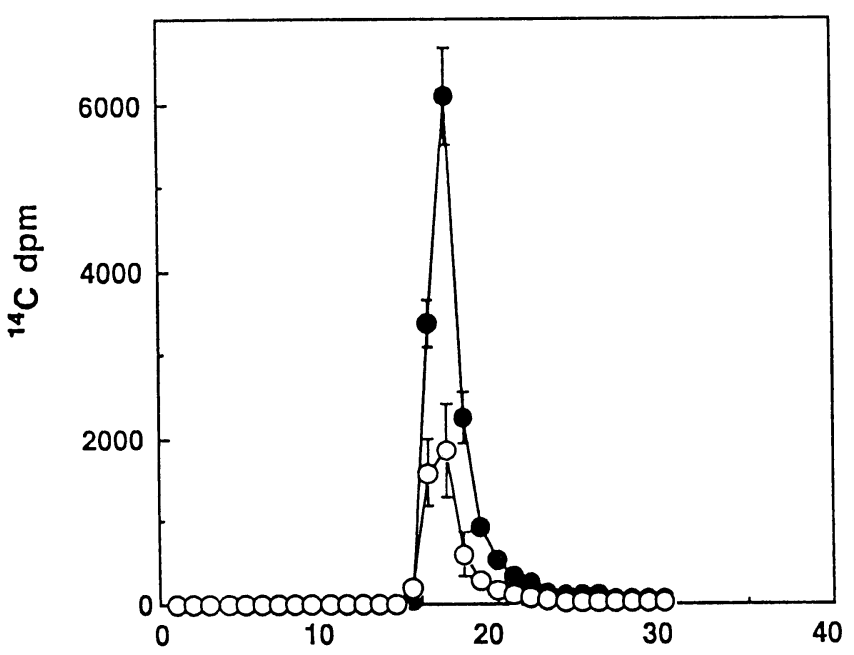

Fraction No.

Fig. 1. tracted lipid were determined by means of enzymatic kits (Kyowa Medex) known as Determiner TG-S555, Determiner PL, Determiner TC-555, and Determiner FC-555, respectively.

$S D S-P A G E$ and autoradiography. After extraction of the lipid of the secreted lipoprotein as described above, the precipitate of the apoproteins was washed with 5\% TCA twice, and proteins were then resolved by electrophoresis on 5-17.5\% acrylamide gradient slab gels (11). After electrophoresis, the gel was treated with $70 \%$ ethanol for $2 \mathrm{~h}$ and $3 \%$ glycerol for 30 min and dried by a gel dryer. The incorporation of ${ }^{3} \mathrm{H}$-leucine into the secreted apoproteins was determined by a Fujix BAS1000 Bio-imaging analyzer (Fuji Photo film Co.).

Proteins on a gel were stained with $0.25 \%$ Coomassie Brilliant Blue R-250 in 45\% ethanol-10\% glacial acetic acid and destained with $25.5 \%$ ethanol-8\% glacial acetic acid. Calibration proteins for high (Boehringer Mannheim) and low (Pharmacia) molecular weight were used.

\section{RESULTS}

Effect of DHA on secretion of a lipoprotein incorporating ${ }^{14} \mathrm{C}$-acetate. Hepatocytes in a $6 \mathrm{~cm}$ dish were incubated in $4 \mathrm{ml}$ of FBS- and insulin-free L-15 containing ${ }^{14} \mathrm{C}$-acetate supplemented with or without $1 \mathrm{mM}$ DHA at $28^{\circ} \mathrm{C}$ for $24 \mathrm{~h}$. The medium of $100 \mu \mathrm{l}$ was then applied to a Superose $12 \mathrm{HR}$ column equilibrated with PBS. As shown in Fig. 1A, eel serum VLDL was separated from fraction number 15 to 20 and the radioactivities were observed in the same range of fractions as shown in Fig. 1B. We have reported previously (24) that

Fig. 1. Fractionation of lipoproteins by a Superose 12 HR 10/30 column. A, Elution profile of eel serum VLDL, HDL, and other serum proteins by a Superose 12 HR column. Eel serum VLDL, HDL, and other serum proteins were prepared by density gradient ultracentrifugation as described previously (24). Protein concentrations of VLDL, HDL, and other serum proteins were $0.64,1.84$, and $3.40 \mathrm{mg}$ $/ \mathrm{ml}$, respectively. Each sample was filtrated with a membrane with $0.45 \mu \mathrm{m}$ pore size (Millipore) and $100 \mu \mathrm{l}$ of the filtrate was applied to a Superose 12 HR column equilibrated with PBS. Lipoproteins and other proteins were eluted with $\mathrm{PBS}$ at a flow rate of $18 \mathrm{ml} / \mathrm{h}$. - VLDL; - - HDL; $-\square-$ Other serum proteins. B, Fractionation of the secreted ${ }^{14} \mathrm{C}$-lipoprotein incorporating ${ }^{14} \mathrm{C}$-acetate by a Superose $12 \mathrm{HR}$ column. Hepatocytes of $1.1 \times 10^{7} /$ dish $(6 \mathrm{~cm})$ were cultured in $4 \mathrm{ml}$ of L-15 medium containing $5 \%$ FBS and $0.16 \mu \mathrm{M}$ insulin for 5 days. Then the medium was changed to $4 \mathrm{ml}$ of FBS- and insulin-free $\mathrm{L}-15$ medium containing $10.57 \mathrm{kBq} / \mathrm{ml}$ of ${ }^{14} \mathrm{C}$-acetate with or without $1 \mathrm{mM} \mathrm{DHA}$, and the hepatocytes were further incubated at $28^{\circ} \mathrm{C}$ for $24 \mathrm{~h}$. After incubation, the medium was centrifuged at 3,000 rpm for $5 \mathrm{~min}$ and the supernatant was filtrated with a membrane with $3.0 \mu \mathrm{m}$ of pore size (Millipore). One hundred $\mu \mathrm{l}$ of the filtrate was applied to a Superose 12 HR 10/30 column equilibrated with PBS and the secreted lipoprotein was eluted with PBS at a flow rate of $18 \mathrm{ml} / \mathrm{h}$. A fraction was collected every $0.5 \mathrm{ml}$ and radioactivity of each fraction was measured with a scintillation counter (Aloka LS3500). The values are maen \pm S.D. for 3 experiments. $-{ }^{14} \mathrm{C}$ lipoprotein secreted by control hepatocytes; - $-{ }^{14} \mathrm{C}$-lipoprotein secreted by DHA-treated hepatocytes. 
Table I. EFFect of DHA on incorporation of ${ }^{14} \mathrm{C}$-ACETATE INTO tRIACYLGLYCEROL (TG), PHOSPHOLIPID (PL), FREE CHOLESTEROL (FC), CHOLESTERYL ESTER (CE), AND FATTY ACIDS (FA) OF SECRETED LIPOPROTEIN.

\begin{tabular}{lcccccc}
\hline \multirow{2}{*}{ Condition } & TG & PL & FC & CE & FA & Total \\
\cline { 2 - 6 } & \multicolumn{5}{c}{$\times 10^{-5} \mathrm{dpm} / \mathrm{mg}$ cell protein } \\
\hline Control (\%) & $1.240(88)$ & $0.107(7.6)$ & $0.044(3.0)$ & $0.006(0.4)$ & $0.015(1.0)$ & $1.410(100)$ \\
+ DHA (1 mM) (\%) & $0.680(88)$ & $0.062(8.0)$ & $0.022(2.8)$ & $0.007(0.9)$ & $0.006(0.7)$ & $0.770(100)$ \\
\hline
\end{tabular}

Hepatocytes were cultured and incubated as described in Fig. 1B. The secreted lipoprotein was isolated by density gradient ultracentrifugation and each lipid of the secreted lipoprotein extracted by methanol and chloroform method was separated by TLC as described in "Materials and Methods". The values are mean for two experiments.

the lipoprotein secreted by cultured eel hepatocytes is a VLDL-like one, and so the radioactivities observed between 15 and 20 were due to the ${ }^{14} \mathrm{C}$-secreted lipoprotein. The radioactivity of ${ }^{14} \mathrm{C}$-lipoprotein secreted by DHA treated cells was about half of that by control cells (Fig. 2A).

To compare the radioactivities of PL, TG, FC, cholesteryl ester (CE), and free fatty acids (FA) extracted from ${ }^{14} \mathrm{C}$-lipoprotein secreted by DHA treated and control cells, the extracted ${ }^{14} \mathrm{C}$-lipid was then applied to TLC. ${ }^{14} \mathrm{C}$-Secreted lipoprotein was prepared by density gradient ultracentrifugation. As shown in Table I, radioactivities of PL, TG, and FC were 42, 45, and 50\% those of control cells, respectively. The sum of PL, TG, $\mathrm{FC}, \mathrm{CE}$, and $\mathrm{FA}$ radioactivities of ${ }^{14} \mathrm{C}$-lipoprotein secreted by DHA treated cells was $45 \%$ that of control cells. These results were consistent with the results shown in Fig. 2A. It was found that $1 \mathrm{mM}$ DHA reduced the secretion of the lipoprotein incorporating ${ }^{14} \mathrm{C}$-acetate in eel hepatocytes.

Effect of DHA on ${ }^{3} \mathrm{H}$-leucine incorporation into intra- and extracellular proteins by cultured hepatocytes. We investigated the effect of DHA on the incorporation of ${ }^{3} \mathrm{H}$-leucine into intra- and extracellular proteins. After $24 \mathrm{~h}$ incubation, the medium was applied to a Superose $12 \mathrm{HR}$ column. The secreted lipoprotein was separated from the other proteins (Fig. 3) and the radioactivity of the ${ }^{3} \mathrm{H}$-lipoprotein was significantly decreased by $1 \mathrm{mM}$ DHA (Table II). DHA did not affect the incorporation of ${ }^{3} \mathrm{H}$-leucine into the other secreted proteins as shown in Table II.

Fig. 2. Effect of DHA on the incorporation of ${ }^{14} \mathrm{C}$-acetate into the secreted lipoprotein and intracellular lipids. A, Incorporation of ${ }^{14} \mathrm{C}$ acetate into the secreted lipoprotein. Hepatocytes $\left(1.1 \times 10^{7}\right.$ cells /dish) were cultured, incubated and the secreted lipoprotein in the medium was fractionated as described in Fig. 1B. The radioactivity of the fractions pooled from No. 15 to 20 as the secreted lipoprotein was measured. The values are mean \pm S.D. for 3 experiments. B, Incorporation of ${ }^{14} \mathrm{C}$-acetate into the intracellular lipid. Hepatocytes of $2 \times$ $10^{7}$ cells $/$ dish $(10 \mathrm{~cm})$ were cultured and incubated as described in Fig. 1B. After incubation, the cells washed with PBS and the intracellular lipids were extracted as described in "Materials and Methods". The values are mean \pm S.D. for 3 experiments. ${ }^{* *}$, Significantly different from the control value. $\mathrm{p}<0.05$.

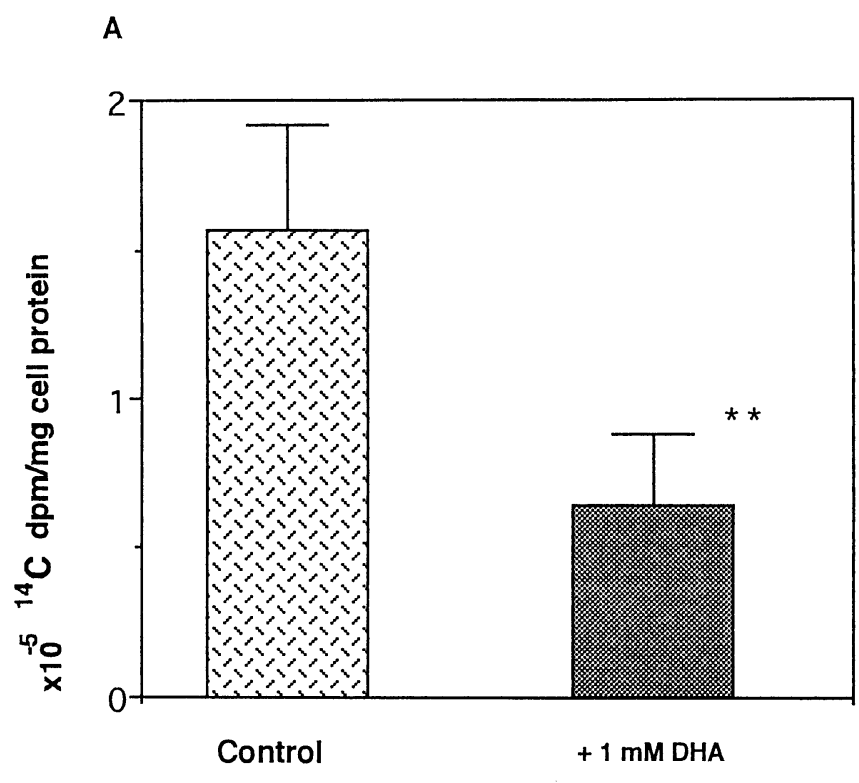

B

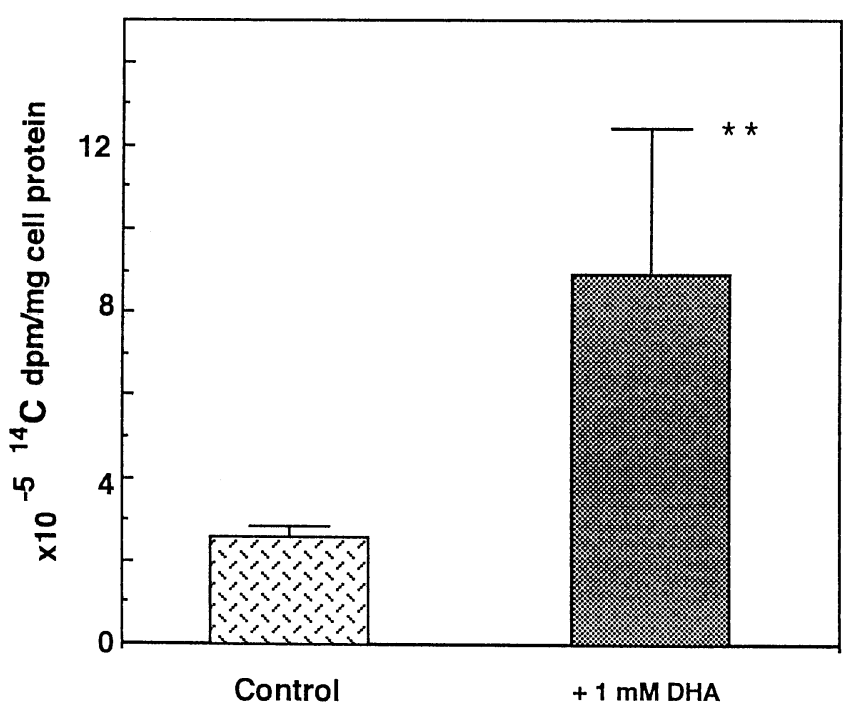

Fig. 2. 


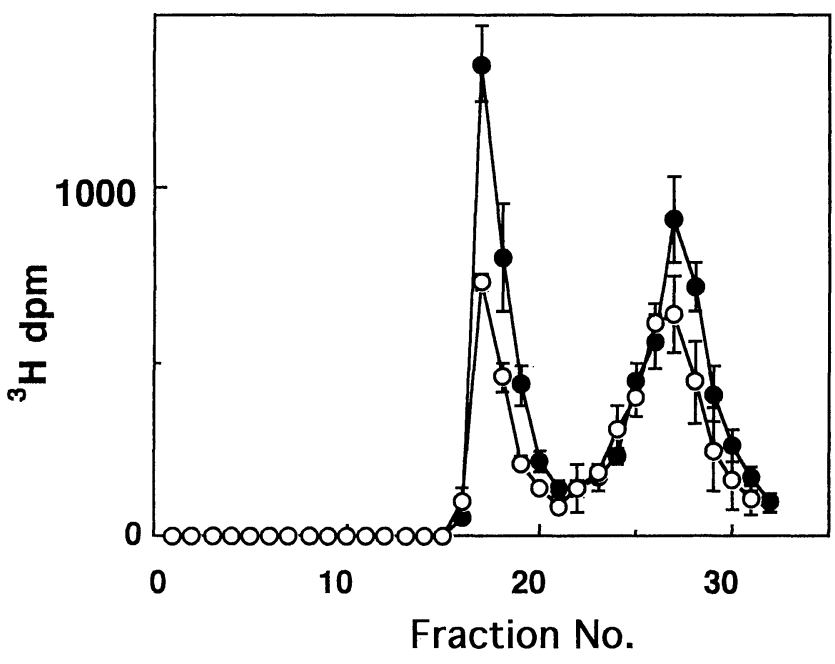

Fig. 3. Fractionation of the secreted proteins incorporating ${ }^{3} \mathrm{H}-\mathrm{leu}-$ cine by a Superose 12 HR 10/30 column. Hepatocytes were cultured as described in Fig. 1B, and incubated in $4 \mathrm{ml}$ of FBS and insulin-free $\mathrm{L}-15$ medium containing $26.43 \mathrm{kBq} / \mathrm{ml}$ of ${ }^{3} \mathrm{H}$-leucine with or without $1 \mathrm{mM}$ DHA at $28^{\circ} \mathrm{C}$ for $24 \mathrm{~h}$. The secreted lipoprotein and other secreted proteins were separated by a Superose 12 HR 10/30 column equilibrated with PBS. A fraction was collected every $0.5 \mathrm{ml}$ and radioactivity of each fraction was measured with a scintillation counter (Aloka LS3500). The values are mean \pm S.D. for 4 experiments. - ${ }^{3} \mathrm{H}$-proteins secreted by control hepatocytes; - $\mathrm{O}-{ }^{3} \mathrm{H}$-proteins secreted by DHA-treated hepatocytes.

After incubation, the hepatocytes were washed with PBS, lysed with $0.1 \mathrm{~N} \mathrm{NaOH}$, and the intracellular proteins were precipitated with TCA. The incorporation of ${ }^{3} \mathrm{H}$-leucine into the intracellular proteins was slightly increased by DHA, but not significantly so (Table II). These results show that DHA specifically reduces the secretion of the lipoprotein incorporating ${ }^{3} \mathrm{H}$-leucine.

We then investigated the effect of DHA on the profile of ${ }^{3} \mathrm{H}$-apoproteins of the secreted lipoprotein. The ${ }^{3} \mathrm{H}$ secreted lipoprotein in the culture medium was prepared by density gradient ultracentrifugation and delipidated by chloroform-methanol method as described in "Materials and Methods". ${ }^{3} \mathrm{H}$-Apoproteins from DHA treated and control cells corresponding to $1.11 \times 10^{5}$ and $1.14 \times 10^{5} \mathrm{dpm}$, respectively, were applied to a SDS-polyacrylamide gradient slab gel. After electro-
A

B

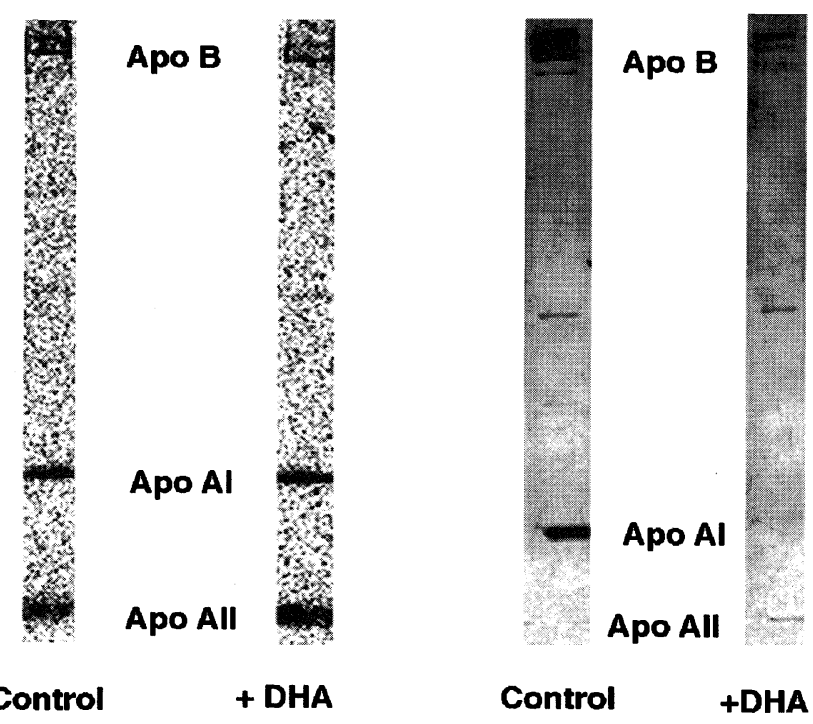

Fig. 4. SDS-PAGE of the lipoprotein secreted by DHA-treated and control hepatocytes. A, Autoradiogram of the ${ }^{3} \mathrm{H}$-apoproteins of the lipoprotein incorporating ${ }^{3} \mathrm{H}$-leucnine. Hepatocytes of $1.1 \times 10^{7}$ cells /dish were incubated in FBS- and insulin-free L-15 medium containing $26.43 \mathrm{kBq} / \mathrm{ml}{ }^{3} \mathrm{H}$-leucine with or without $1 \mathrm{mM} \mathrm{DHA}$ at $28^{\circ} \mathrm{C}$ for $24 \mathrm{hr}$. After incubation, $1.75 \mathrm{ml}$ of the medium was applied to density gradient ultracentrifugation and fractions were collected every $200 \mu \mathrm{l}$ from the top of a centrifuge tube. The secreted lipoprotein $(200 \mu \mathrm{l})$ taken from the top was delipidated by chloroform-methanol method as described in "Materials and Methods". Then the apoproteins were dissolved with $60 \mu \mathrm{l}$ of sample buffer for SDS-PAGE and the sample was applied to a $5-17.5 \%$ gradient slab gel. The amounts of the radioactivity of the loaded samples prepared from DHA-treated and control cells were $1.11 \times 10^{5}$ and $1.14 \times 10^{5} \mathrm{dpm}$, respectively. After SDSPAGE, the gel was dried and exposed to a Fuji imaging plate at room temperature for one week and analyzed by a Fujix Bas1000 Bio-imaging Analyzer (Fuji Photo Film Co.). B, SDS-PAGE of the lipoprotein secreted by DHA-treated and control hepatocytes. After 5 days culture, hepatocytes of $2 \times 10^{7}$ cells/dish were incubated with $7 \mathrm{ml}$ of FBS- and insulin-free L-15 medium with or without $1 \mathrm{mM}$ DHA at $28^{\circ} \mathrm{C}$ for $24 \mathrm{~h}$. The secreted lipoprotein was fractionated by density gradient ultracentrifugation and delipidated by methanol and chloroform method. Apoproteins of 11.3 and $74.0 \mu \mathrm{g}$ secreted by DHAtreated and control cells, respectively, were applied to a $5-17.5 \%$ gradient slab gel. After SDS-PAGE, the proteins on the gel was stained and destained as described in "Materials and Methods".

Table II. EFFeCt of DHA ON INCORPORATION of ${ }^{3} \mathrm{H}$-LEUCINE INTO INTRA- AND EXTRA-CELLULAR PROTEINS.

\begin{tabular}{|c|c|c|c|c|}
\hline \multirow{3}{*}{ Condition } & \multirow{2}{*}{ Intracellular Protein } & \multicolumn{2}{|c|}{ Extracellular Protein } & \multirow{3}{*}{ Protein $\mathrm{mg} / \mathrm{disl}$} \\
\hline & & Lipoprotein & Other protein & \\
\hline & \multicolumn{3}{|c|}{$\times 10^{-4} \mathrm{dpm} / \mathrm{mg}$ cell protein } & \\
\hline Control & $31.01 \pm 1.71$ & $4.93 \pm 0.55$ & $6.32 \pm 0.68$ & $2.43 \pm 0.04$ \\
\hline+ DHA $(1 \mathrm{mM})$ & $35.62 \pm 5.12$ & $2.95 \pm 0.26^{*}$ & $5.68 \pm 0.87$ & $2.27 \pm 0.15$ \\
\hline
\end{tabular}

Hepatocytes were cultured and incubated as described in Fig. 3. Intra- and extracellular proteins were prepared as described in "Materials and Methods". The values are mean \pm S.D. for 4 experiments.

* Significantly different from the control value. $\mathrm{p}<0.01$ 
Table III. COMPOSITION OF THE LIPOPROTEIN SECRETED BY DHA-TREATED AND CONTROL HEPATOCYTES.

\begin{tabular}{|c|c|c|c|c|c|}
\hline \multirow{2}{*}{ Condition } & Protein & TG & PL & TC & Lipoproein \\
\hline & \multicolumn{5}{|c|}{$\mu \mathrm{g} / \mathrm{mg}$ cell protein $/ 24 \mathrm{~h}$} \\
\hline Control (\%) & $\begin{array}{c}28.03 \pm 6.09 \\
(17.5)\end{array}$ & $\begin{array}{c}118.24 \pm 19.02 \\
(71.5)\end{array}$ & $\begin{array}{c}17.59 \pm 5.80 \\
(10.5)\end{array}$ & $\begin{array}{c}0.79 \pm 0.29 \\
(0.5)\end{array}$ & $\begin{array}{c}164.65 \pm 19.16 \\
(100)\end{array}$ \\
\hline + DHA (1 mM) (\%) & $\begin{array}{c}3.42 \pm 0.41^{*} \\
(13.1)\end{array}$ & $\begin{array}{c}20.16 \pm 6.94^{*} \\
(73.6)\end{array}$ & $\begin{array}{c}3.61 \pm 1.46^{* *} \\
(12.9)\end{array}$ & $\begin{array}{c}0.16 \pm 0.06^{* *} \\
(0.6)\end{array}$ & $\begin{array}{c}27.34 \pm 8.76^{*} \\
(100)\end{array}$ \\
\hline
\end{tabular}

Hepatocytes were cultured and incubated as described in Fig. 4B. The secreted lipoprotein was isolated by density gradient ultracentrifugation and TG, PL, and TC were assayed by enzymatic method as descibed in "Materials and Methods". The values are mean \pm S.D. for 3 experiments.

* Significantly different from the control value. $\mathrm{p}<0.01$

** Significantly different from the control value. $\mathrm{p}<0.05$

phoresis, each ${ }^{3} \mathrm{H}$-apoprotein was detected with a Fujix BAS1000 Bio-imaging Analyzer (Fuji Photo Film Co.). As shown in Fig. 4A, the profiles of ${ }^{3} \mathrm{H}$-apoproteins from DHA treated and control cells were the same. These results assume that DHA does not affect the synthesis or secretion of any particular apoprotein, but affects the synthesis or secretion of a whole lipoprotein particle.

Effect of DHA on content of protein, triacylglycerol, phospholipid, and cholesterol of the secreted lipoprotein. Effect of DHA on content of protein and lipid consisting of the secreted lipoprotein was investigated. As shown in Table III, contents of protein, TG, PL, total cholesterol (TC) of the lipoprotein secreted by DHA treated hepatocytes were 12, 17, 21, and 20\% compared to those of control cells, respectively. The amount of secretion of the lipoprotein per $24 \mathrm{~h}$ by DHA treated cells was $27.34 \mu \mathrm{g} / \mathrm{mg}$ cell protein, which corresponded to $17 \%$ of that by control cells.

The chemical compositions of the lipoprotein secreted by DHA treated and control cells were almost the same (Table III). TG was a main component of both secreted lipoproteins and about $70 \%$. Protein ratio of the lipoprotein secreted by control cells was slightly higher than that of the lipoprotein secreted by DHA-treated cells.

Apoprotein composition by SDS-PAGE was also investigated on the lipoprotein secreted by DHA treated and control cells. As shown in Fig. 4B, apoprotein compositions of both the secreted lipoproteins were the same. Major apoproteins were apo AI $(24 \mathrm{kDa})$, AII $(13 \mathrm{kDa})$, and $\mathrm{B}(260 \mathrm{kDa})$ in both lipoproteins as re-

Table IV. Specific activity of the Composition of THE LIPOPROTEIN SECRETED BY DHA-TREATED AND CONTROL HEPATOCYTES.

\begin{tabular}{lrrrr}
\hline \multirow{2}{*}{ Condition } & \multicolumn{4}{c}{ Secreted Lipoprotein } \\
\cline { 2 - 5 } & Protein & \multicolumn{1}{c}{ TG } & PL & \multicolumn{1}{c}{ TC } \\
\cline { 2 - 5 } & \multicolumn{5}{c}{$\mathrm{dpm} / \mu \mathrm{g}$} \\
\hline Control & 176 & 966 & 1049 & 6329 \\
+ DHA $(1 \mathrm{mM})$ & 863 & 1717 & 3373 & 18125 \\
\hline
\end{tabular}

The values are calculated from Tables I, II, and III. ported previously (24). The profile of apoproteins by protein staining was consistent with that of ${ }^{3} \mathrm{H}$-apoproteins by autoradiography.

Specific activities of the protein, TG, PL, and $\mathrm{CH}$ of the secreted lipoprotein incorporating ${ }^{14} \mathrm{C}$-acetate or ${ }^{3} \mathrm{H}$-leucine were calculated from Tables I, II and III. As shown in Table IV, specific activities of each component of the lipoprotein secreted by DHA treated cells were higher than those by control cells. The specific activity of apoproteins of the lipoprotein secreted by DHA treated cells was particularly higher, 4.9-fold, than that by control cells. These specific activities seem to reflect the intracellular lipoprotein synthesis. It is suggested that intracellular lipoprotein synthesis is stimulated by DHA. Hence we investigated the effect of DHA on lipid synthesis.

Effect of DHA on lipid synthesis from ${ }^{14} \mathrm{C}$-acetate. Hepatocytes in a $6 \mathrm{~cm}$ dish were incubated in $4 \mathrm{ml}$ of FBS- and insulin-free L-15 containing ${ }^{14} \mathrm{C}$-acetate with or without $1 \mathrm{mM} \mathrm{DHA}$ at $28^{\circ} \mathrm{C}$ for $24 \mathrm{~h}$ and after incubation, intracellular lipid was extracted. The incorporation of ${ }^{14} \mathrm{C}$-acetate into the extracted lipid was stimulated 3.5-fold by $1 \mathrm{mM}$ DHA (Fig. 2B). After separation of lipid components by TLC, radioactivities of TG, PL, FC, and CE were determined and those of TG, PL, FC, and CE of DHA-treated cells were 9.7-, 1.0-, 1.6-, and 8.5-fold, respectively, compared to those of control cells (Table V). These results indicate the stimulative effect of DHA on lipid synthesis.

Effect of DHA on content of intracellular lipid. Lipid was extracted from DHA treated and control cells and their intracellular TG, PL, and TC were deter-

Table V. EFfect of DHA on LIPID Synthesis.

\begin{tabular}{lrccc}
\hline \multirow{2}{*}{ Condition } & \multicolumn{1}{c}{ TG } & PL & FC & CE \\
\cline { 2 - 5 } & \multicolumn{5}{c}{$\times 10^{-4} \mathrm{dpm} / \mathrm{mg}$ cell protein } \\
\hline Control & 7.43 & 9.69 & 2.64 & 0.18 \\
+ DHA $(1 \mathrm{mM})$ & 72.28 & 9.73 & 4.14 & 1.54 \\
\hline
\end{tabular}

Hepatocytes were cultured as described in Fig. 1-B. Intracellular lipid was extracted and separated by TLC as described in "Materials Methods". The values are mean for 2 experiments. 
Effect of Docosahexaenoic Acid on Eel Hepatocytes

Table Vi. Effect of DHA on content of intracellular triacylglycerol (TG), PHOSPholipid (PL), AND total ChOleSterol (TC).

\begin{tabular}{lllll}
\hline \multirow{2}{*}{ Condition } & \multicolumn{1}{c}{ TG } & \multicolumn{2}{c}{ PL } & \multicolumn{2}{c}{ Total } \\
\cline { 2 - 5 } Control & \multicolumn{4}{c}{$\mu \mathrm{g} / \mathrm{mg}$ cell protein $/ 24 \mathrm{~h}$} \\
+ DHA $(1 \mathrm{mM})$ & $112.87 \pm 22.70$ & $183.41 \pm 19.86$ & $4.26 \pm 1.04$ & $360.71 \pm 80.75$ \\
\hline
\end{tabular}

Hepatocytes were cultured and incubated as described in Fig. 4B. Intracellular lipid was extracted, dissolved in 5\% Triton X-100, and assayed by enzymatic method as described in "Materials and Methods". The values are mean \pm S.D. for 3 experiments.

* Significantly different from the control value. $\mathrm{p}<0.01$

mined by enzymatic methods. DHA at $1 \mathrm{mM}$ increased intracellular TG, PL, and TC content by 4.8-, 1.6-, and 1.8 -fold, respectively (Table VI). Specific activities of TG and TC of DHA-treated cells calculated from Table $\mathrm{V}$ and VI were 2- and 1.1-fold, respectively, compared to those of control cells. These results indicate that lipid synthesis is stimulated by DHA, and are consistent with the results shown in Table IV. The accumulation of these lipid induced by DHA seems to be due to the stimulation of lipid synthesis (Fig. 2B and Table V) and the reduction of the rate of lipoprotein secretion by DHA (Table I, II, and III). Since about $70 \%$ of the secreted lipoprotein consists of TG (Table III), if secretion of the lipoprotein is inhibited, the content of intracellular TG seems to increase, and it is suggested that TG was particularly accumulated in DHA treated cells.

\section{DISCUSSION}

We have observed three remarkable characteristics on the effect of DHA on synthesis and secretion of lipoprotein in cultured eel hepatocytes. The first is that intracellular lipid synthesis was stimulated by DHA. This was deduced from the results that DHA increased intracellular lipid synthesis from ${ }^{14} \mathrm{C}$-acetate by 3.5 -fold (Fig. 2B) and intracellular TG, FC, and CE syntheses in DHA-treated cells were 9.7-, 1.6-, and 8.5-fold, respectively (Table V). The specific activity of intracellular TG was 2 times higher than that of control. The increase in lipid synthesis and the specific activity of TG seems to reflect the specific activities of lipid of the secreted lipoprotein (Table IV) and the specific activities of TG, PL, and TC of the lipoprotein secreted by DHA treated cells were $1.8,3.2$, and 2.9 times higher, respectively, than those by control cells. It was reported that DHA and EPA stimulated degradation of apo B protein and this degradation was the reason to reduce VLDL secretion since apo B is essential for VLDL assembly (20). The lipoprotein secreted by eel hepatocytes contains apo B corresponding to apo B48 as a main apoprotein (24), but by the higher specific activity of apoproteins secreted by DHA-treated cells it would be difficult to explain the increase of apo B degradation (Table IV). There are many reports describing the inhibitory effect of DHA or EPA on intracellular lipid synthesis $(7,15,16)$. These reports compare EPA-treated and oleic acid-treated cells. Recently Lin et al. (12), using primary human hepatocytes, reported that EPA-treated cells synthesized intracellular lipid at higher rate than control cells incubated with only bovine serum albumin, but at lower rate than oleic-acid-treated cells. Stimulatory effects of DHA and EPA on TG synthesis were also reported using primary culture of rat hepatocytes by Wang et al. (20), who described that $0.8 \mathrm{mM}$ DHA stimulated TG synthesis 2fold compared to TG synthesis by control cells. Inhibitory effect of EPA on acyl-CoA: 1,2-diacylglycerol acyltransferase was reported (17) and its activity seems particularly to affect TG synthesis from diacylglycerol (DG), suggesting that DG synthesis is more stimulated than TG synthesis by EPA- or DHA-treated cells as reported by Lin et al. (12).

The second characteristic is that DHA inhibits the secretion of lipoprotein. The amounts of radioactivity and contents of the secreted lipoprotein were reduced by DHA as shown in Table I, II, and III. Radioactivity of lipids such as TG, PL, FC, CE, and FA of the secreted lipoprotein as measured by the amounts of ${ }^{14} \mathrm{C}$ acetate incorporated by these lipid in DHA-treated cells was $54.6 \%$ of that of control cells and similarly, radioactivity of apoproteins of the secreted lipoprotein incorporating ${ }^{3} \mathrm{H}$-leucine in DHA-treated cells was $59.8 \%$ of that of control (Table I and II). Furthermore, DHA specifically reduced the amounts of ${ }^{3} \mathrm{H}$-leucine incorporated by the secreted lipoprotein, but not by the other secreted proteins (Table II). The amount of lipoprotein secreted by DHA-treated cells was $16.6 \%$ of that by control cells (Table III). These results indicate that DHA remarkably inhibits the secretion of lipoprotein. However, the syntheses of particular lipid and apoproteins of the secreted lipoprotein was not affected by DHA. Though the amount of radioactivity in the secreted lipoprotein incorporating ${ }^{14} \mathrm{C}$-acetate was reduced by DHAtreated cells, the distribution of radioactivity between TG, PL, FC, and CE of the lipoprotein secreted by DHA-treated and control cells was the same (Table I). The chemical composition of the lipoprotein secreted by DHA-treated and control cells was also the same (Table IV). Similarly, the profile of apoproteins determined from protein-staining or autoradiogram after SDS-PAGE of the lipoprotein secreted by DHA-treated 
and control cells was the same (Fig. 4). These results suggest that DHA did not affect the particular lipid and apoproteins synthesis, but affected the assembly or secretion of a lipoprotein particle.

The third characteristic is that DHA induced the accumulation of intracellular lipid. The intracellular contents of TG, PL, and TC were increased in the DHAtreated cells by $4.8-, 1.6-$, and 1.8 -fold, respectively (Table VI). The accumulation of these lipid induced by DHA seems to be due to the stimulation of lipid synthesis and the reduction of the rate of lipoprotein secretion by DHA. The fact that the most increased lipid in the DHA-treated cells was TG seems due to decreasing the secretion of lipoprotein, since about $70 \%$ of the secreted lipoprotein consists of TG as shown in Table III. The induction of the increase in TG content in DHAtreated hepatocytes of eel were consistent with the report by Yaqoob et al. (23), who conducted experiments on fish oil feeding using rats and found that the liver of rat fed fish oil contained higher amount of TG than the liver of control rat fed low fat.

These three characteristics described above together with recent reports using cultured human (12) and rat (20) hepatocytes indicate that DHA inhibits the assembly or the secretion of lipoprotein and that there is no difference of the primary action of DHA on lipoprotein metabolism by eel and mammalian hepatocytes. However, in cultured eel hepatocytes addition of eel serum VLDL or HDL, in spite of its containing DHA and EPA, stimulates the synthesis and secretion of lipoprotein $(14,25)$. The amount of free DHA or EPA produced, if any, from the decomposition of incorporated VLDL or HDL is rather small, and they could not inhibit the secretion of lipoprotein as described in this paper. Though we have not determined intracellular DHA and EPA content, the ratio of intracellular TG, PL, FC, and CE to free DHA and EPA in serum VLDL- or HDL-treated cells seems to be lower than that in DHAtreated cells. The low ratio seems to stimulate the synthesis and secretion of lipoprotein by serum VLDL- or HDL-treated cells. The increased production of fatty acids containing DHA and EPA leads to increased inhibition of the secretion of a lipoprotein. However, the sensitivity of DHA or EPA to inhibit lipoprotein assembly and secretion seems different among animals. TG secretion through VLDL by EPA-treated human hepatocytes was lower than that by control cells, but in EPAtreated rat hepatocytes TG secretion was the same extent with that in control cells (12). When compared to rat hepatocytes, human hepatocytes are more sensitive to DHA in terms of its effect on lipoprotein secretion than rat cells. The sensitivity to DHA in eel hepatocytes seems to be similar to human hepatocytes since the inhibitory effect on TG secretion in the former and the latter was over $80 \%$ and $40 \%$ (13), respectively.
Acknowledgments. We thank Katsuya Ueno and Tsuyoshi Egawa for assistance with cell culture and other technical support. This work was supported by a grant-in-aid for general scientific research to S. Hayashi from the Ministry of Education, Science and Culture of Japan.

\section{REFERENCES}

1. ANIL, K. and Sudhakaran, P.R. 1995. Effect of feeding sardine oil on synthesis and secretion of apolipoprotein B-containing lipoproteins by rabbit hepatocytes. Nutrition, 11: 17-21.

2. BeLL, M.V. and Dick, J.R. 1991. Molecular species composition of the major phospholipids from muscle, liver, retina and brain of cod (Gadus morthua). Lipids, 26: 565-573.

3. BRADFORD, M.M. 1976. A rapid and sensitive method for the quantitation of microgram quantities of protein utilizing the principle of protein dye binding. Anal. Biochem., 72: 248-254.

4. Chung, B.H., Wilkinson, T., Greer, J.C., and Segrest, J.P. 1980. Preparative and quantitative isolation of plasma lipoproteins: Rapid single discontinuous density gradient ultracentrifugation. J. Lipid Res., 21: 284-291.

5. Furuita, H., Takeuchi, T., Watanabe, T., Fujimoto, H., SeKiya, S., and Imaiumi, K. 1996. Requirement of larval yellowtail for eicosapentaenoic acid, dososahexaenoic acid, and n3 highly unsaturated fatty acids. Fisheries Science, 62: 372-379.

6. Harris, W.S., Conner, W.E., and Murry, M.P. 1983. The comparative reductions of the plasma lipids and lipoproteins by dietary polyunsaturated fats: salmon oil versus vegetable oils. Metabolism, 32: 179-184.

7. HARRIS, W.S. 1989. Fish oils and plasma lipid and lipoprotein metabolism in humans: a critical review. J. Lipid Res., 30: 785803.

8. HaYASHI, S. and Ooshiro, Z. 1978. Preparation of isolated cells of eel liver. Bull. Japan. Soc. Sci. Fish., 44: 499-503.

9. HaYAShI, S. and Ooshiro, Z. 1985. Primary culture of the freshly isolated liver cells of the eel. Bull. Japan. Soc. Sci. Fish., 51: $765-771$.

10. JiANG, Z. and Sim, J. 1993. Consumption of n-3 polyunsaturated fatty acid-enriched eggs and changes in plasma lipids of human subjects. Nutrition, 9: 513-518.

11. LAEMmLI, U.K. 1970. Cleavage of structural proteins during the assembly of the head of bacteriophage T4. Nature, 227: 680-685.

12. Lin, Y., Smit, M.J., Havinga, R., Verkade, H.J., VonK, R.J., and KUIPERS, F. 1995. Differential effects of eicosapentaenoic acid on glycerolipid an apolipoprotein B metabolism in primary human hepatocytes compared to Hep G2 cells and primary rat hepatocytes. Biochim. Biophys. Acta, 1256: 88-96.

13. von LosSONXZY, T.O., RUITER, A., BRONSQEEST-SCHUTE, H.C., van Gant, C.M., and Hermus, R.J.J. 1978. The effect of a fish diet on serum lipids in healthy human subjects. Am. J. Clin. Nutr., 31: 1340-1346.

14. Ndiaye, J., Mori, Y., Tanaka, Y., Sakata, T., Miki, H., SaKakibara, T., Sato, M., and Hayashi, S. 1995. Effect of specific binding of high density lipoprotein to eel hepatocytes on their secretion of lipoprotein. Cell Struct. Funct., 20: 301-310.

15. Nossen, J.Ø., Rustan, A.C., Gloppestad, S.H., Målbakken, S., and Drevon, C.A. 1986. Eicosapentaenoic acid inhibits synthesis and secretion of triacylglycerol by cultured rat hepatocytes. Biochim. Biophys. Acta., 879: 56-65.

16. Ribeiro, A., Mangeney, M., Cardot, P., Loriette, C., Rayssiquer, Y., Chambaz, J., and Bereziat, G. 1991. Effect 
of dietary fish oil and corn oil on lipid metabolism and apolipoprotein gene expression of rat liver. J. Biol. Chem., 196: 499507.

17. Rustan, A.C., Nossen, J.O., Christiansen, E.N., and Drevon, C.A. 1988. EPA reduces hepatic synthesis and secretion of triacylglycerol by decreasing the activity of acyl-coenzyme A: 1,2-diacylglycerol acyltransferase. J. Lipid Res., 29: $1417-1426$.

18. Shikata, T. and Shimeno, S. 1994. Metabolic response to dietary stearic acid, linoleic acid, and highly unsaturated fatty acid in carp. Fisheries Science, 60: 735-739.

19. Smith, P.K., Krohn, R.I., Hermanson, G.T., Mallia, A.K., Gartner, F.H., Provenzano, M.D., Fujimoto, E.K., Goeke, N.M., Olson, B.J., and KlanK, D.C. 1985 . Measurement of protein using bicinchoninic acid. Anal. Biochem., 150: 76-85.

20. WANG, H., Chen, X., and Fisher, E.A. 1993. N-3 Fatty acids stimulate intracellular degradation of apoprotein B in rat hepatocytes. J. Clin. Invest., 91: 1380-1389.

21. Watanabe, T. 1982. Lipid nutrition in fish. Comp. Biochem. Physiol., 73B: 3-15.
22. Watanabe, T. 1993. Importance of docosahexaenoic acid in marine larvae fish. J. World Aquacult. Soc., 24: 152-161.

23. Yaqoob, P., Sherrington, E.J., JefFery, N.M., SANDerson, P., Harvey, D.J., Newsholme, E.A., and Calder, P.C. 1995. Comparison of the effects of a range of dietary lipids upon serum and tissue lipid composition in the rat. Int. J. Biochem. Cell Biol., 27: 297-310.

24. Yu, F.-G., ANDo, S., and HaYASHI, S. 1991. Characterization of lipoprotein secreted by cultured eel hepatocytes and its comparison with serum lipoproteins. Cell Struct. Funct., 16: 347355.

25. Yu, F.-G., ANDo, S., and HaYAShI, S. 1992. Effects of insulin, eel serum very low density lipoprotein, and high density lipoprotein on lipoprotein synthesis and secretion by cultured hepatocytes of eel (Anguilla japonica). Comp. Biochem. Physiol., 101B: $333-339$.

(Received for publication, August 21, 1996

and in revised form, October 7,1996 